Note

\section{On Cell Wall Lytic Enzymes Produced by Corticium centrifugum}

\author{
Satoshi Uehara, ${ }^{* 1}$ Kiyozo HasegawA*2 \\ and Kazuo IwAI*3 \\ Research Institute for Food Science, Kyoto University, \\ Uji, Kyoto 611, Japan \\ *2Department of Food Science and Nutrition, \\ Nara Women's University, Nara 630, Japan \\ Received April 9, 1979
}

Sugimori et al. ${ }^{12}$ reported the presence of a strong cell wall lytic enzyme activity, which could lyse even living yeast cells, in Corticium centrifugum IAM 9028 as a result of screening tests. The enzymes responsible for the lysis of yeast cell wall, however, have not been identified yet in this mold. The present paper describes studies on the additive effect of protease to the heattreated enzyme preparation of $C$. centrifugum. In this examination, as the protease to be added, pepsin ( $2 \times$ cryst., Sigma) was used as substitute for the protease of $C$. centrifugum.

As a sample yeast, Lipomyces starkeyi IFO 0678, which is known as a lipid productive yeast, was used, and cultured in a medium consisting of $3 \%$ glucose, $1 \%$ peptone, $0.3 \%$ yeast extract, $0.4 \% \mathrm{~K}_{2} \mathrm{HPO}_{4}, 0.2 \%$ $\mathrm{KH}_{2} \mathrm{PO}_{4}$ and $0.025 \% \mathrm{MgSO}_{4} \cdot 7 \mathrm{H}_{2} \mathrm{O}$, at $30^{\circ} \mathrm{C}$ with shaking. Cells in the stationary phase of growth were harvested by centrifugation, and washed four times with $0.9 \% \mathrm{NaCl}$ solution. Washed cells were suspended in $0.1 \mathrm{M}$ acetate buffer, $\mathrm{pH} 3.4$, to make the optical dencity at $660 \mathrm{~nm}$ about 1.5 . A mixture of $3 \mathrm{ml}$ of yeast cell suspension, $0.5 \mathrm{ml}$ of enzyme solution and

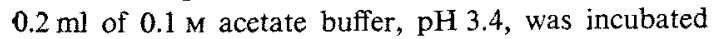
at $30^{\circ} \mathrm{C}$ with shaking at a rate of 120 times per min. Then the decrease in the optical density of the mixture was measured at $660 \mathrm{~nm}$ with time. Reference contained the same components except $0.5 \mathrm{ml}$ of water instead of the enzyme solution. Lytic activity was calculated from the following formula: $:^{23}$ Lytic activity = (OD $660 \mathrm{~nm}$ of reference - OD $660 \mathrm{~nm}$ of reaction mixture) $\times 100 \times$ dilution rate / initial $O D 660 \mathrm{~nm}$ of reference. Lytic activity was also measured by calculating cell number using a microscope. Protease activity was measured by using casein as substrate. ${ }^{3)}$

C. centrifugum IAM 9028 was cultured as described previously ${ }^{4)}$ in Czapek-Dox medium except that $4 \%$

*1 Present address: Kagawa University, Kagawa, Japan.

*8 To whom reprint requests should be addressed. of heat-treated brewer's yeast was used instead of sucrose. The culture filtrate was saturated with solid ammonium sulfate, and left overnight with stirring. The resulting precipitate was collected by centrifugation and dissolved in $0.05 \mathrm{M}$ Tris- $\mathrm{HCl}$ buffer, $\mathrm{pH}$ 7.1. The solution was desalted by passing through Sephadex G-25 column, which had been equilibrated with the same buffer. The desalted solution was lyophilized, and used as a crude enzyme preparation.

The crude enzyme preparation was dissolved in $0.05 \mathrm{M}$ Tris-malate- $\mathrm{NaOH}$ buffer, $\mathrm{pH} 7.0$, and incubated at $50^{\circ} \mathrm{C}$ for $15 \mathrm{~min}$. The heat-treated enzyme preparation (H-enzyme) lost $88 \%$ of protease activity.

After the addition of pepsin to H-enzyme, the decrease in the optical density was measured with time at $660 \mathrm{~nm}$. The amount of the addition of pepsin was made equivalent to that which was lost by heat-treatment. The result of the additive effect is shown in Fig. 1. No lysis of living yeast cells was detected with

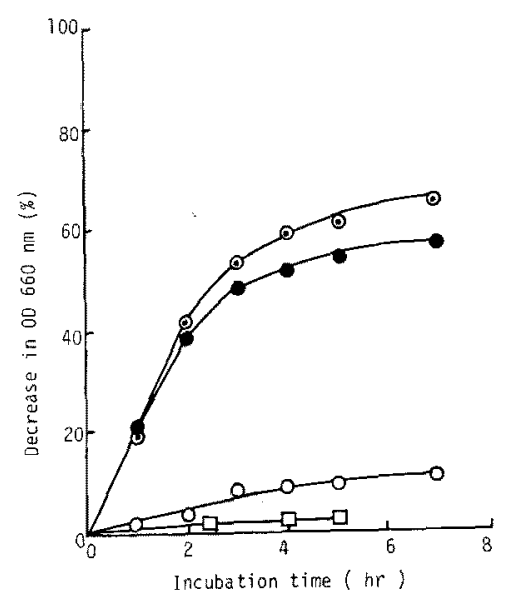

Fig. 1. Lysis of Living Yeast Cells.

The lytic activities were determined under the standard assay condition.

$\odot-\odot$, crude enzyme; $\bigcirc-\bigcirc$, H-enzyme; $\square-\square$, pepsin;

-- H-enzyme + pepsin.

H-enzyme or pepsin alone. However, when pepsin was added to $\mathrm{H}$-enzyme, lytic activity, which was equal to that of crude enzyme, was shown. It was also observed under a microscope that cell number decreased to half and the shape of cells became smaller after the incubation for $7 \mathrm{hr}$.

These results showed that although pepsin could not lyse by itself living yeast cells, it could lyse them by cooperating with the heat-treated enzyme preparation of $C$. centrifugum. From the above results, it was suggested that acid protease of $C$. centrifugum played an important role in the lysis of living yeast cells. 


\section{REFERENCES}

1) T. Sugimori, Y. Uchida and Y. Tsukada, Agric. Biol. Chem., 36, 669 (1972).

2) T. Obata, K. Fujioka, S. Hara and Y. Namba, ibid., 41, 671 (1977).

3) A. Kaji and K. Tagawa, Nippon Nogeikagaku Kaishi, 40, 325 (1966).

4) S. Uehara, K. Hasegawa and K. Iwai, Agric. Biol. Chem., 43, 517 (1979). 